\title{
EHEALTH IN THE EUROPEAN UNION - COMPARATIVE STUDY
}

\author{
Eva Ardielli \\ VŠB - Technical University of Ostrava, Faculty of Economics, \\ Department of Public Economics, \\ Sokolská 33, 70200 Ostrava, Czech Republic \\ e-mail: eva.ardielli@vsb.cz
}

\begin{abstract}
eHealth is one of the global modern trends in IT, medicine and politics. It is a broad term that refers to electronization of healthcare and health services and mainly describes the use of information and communication technologies in healthcare. In practice, the evaluation of eHealth is an important matter because it leads to selection of appropriate measures for further progress in the field of electronic healthcare. What is more, it proposes recommendations for the development of eHealth in the EU countries. The article is focused on the comparison of eHealth implementation in the European Union member states. The analysis is performed by means of ELECTRE III method. The results of the empirical research further evaluate the state of eHealth implementation in all European Union member states by selected criteria and enable the comparison of the eHealth implementation in the international context. The results are verified by application of MAPPAC method. It has been acknowledged that the best ranking countries in this area has been obtained by Denmark, Finland, Estonia and Sweden.
\end{abstract}

\section{Keywords}

eHealth; ELECTRE III; Evaluation; EU countries.

\section{Introduction}

Nowadays, the right to healthcare is legally anchored in the constitutions of most democratic countries. Generally, healthcare is considered by society as a public good that should be available to everyone and in the same extent. It is an important and necessary element in the whole socio-economic sphere [16]. The quality health system is, together with good health of citizens, the priority of all developed countries. Healthcare has become one of the most important economic sectors in the last few decades. This tendency is reinforced by the fact that it is unconditional of all national residents and also by the fact that spending on health services has been rising in European Union countries in long term [21], [20]. The main reason of this trend is connected with the consequence of demographic change (ageing population) and the improvements in medical treatment in Europe. Another factor influencing the growth of expenditures in this area is in great extend the involvement of information and communication technologies (ICT). ICT implementation in healthcare is a rapidly evolving and expensive resort, which is why financial demand of healthcare is increasing [13].

eHealth and mHealth are well-known current concepts in the medical field of ICT [2]. eHealth appeared at the turn of the 20th to the 21st century. This abbreviation is analogous to concepts related to electronization in many other areas [22]. It represents mainly the health service supported by ICT [17], [1]. As a sub-segment of eHealth, mHealth, which stands for mobile health [14], emerged. The term is most commonly used in reference to using mobile communication devices, such as mobile phones, tablet computers and personal digital assistants (PDAs), and wearable devices such as smart watches, for health services, 
information, and data collection [4]. eHealth has quickly become a symbol of the democratization of healthcare, as well as an opportunity to meet the challenges caused by an ageing society, the epidemic of non-communicable and chronic diseases and the dramatically rising costs of healthcare [3], [5].

\section{1 eHealth in the European Union}

ICT has become a truly revolutionary part of European healthcare in recent years. Although eHealth tools and services have been well established in many EU countries and commonly used today, individual healthcare facilities, hospitals, and physicians very often chose the best, individual system for themselves without any coordination. Thus, the implementation of eHealth in individual European member states is greatly fragmented and disparate nowadays. Therefore, the potential cross-system communication is here yet one of the main steps that can encourage and enhance the benefits of computerization. For this reason, the aim of the European Union health policy is to link and coordinate individual national eHealth projects. This effort is also a part of the eEurope Action Plan, approved in 2000 [9]. Coordination includes fast access to shared and remote medical expertise through telecommunication and information technology, no matter where the patient or relevant information is located [23].

In the European Union, where people are absolutely free to move to other EU member states, there is a need to engage in mutual communication that should ensure the highest standards of health care, wherever the patients are. The main aim is to build a common European eHealth space that will successfully solve this problem and thus become one of the main objectives of the European Commission's work. In 2012, the eHealth-focused working group of European Commission produced a report on "Redesign of Health in Europe by 2020", see [10], highlighting the major challenges that prevent the reorganization of European healthcare with the use of existing information technology [15]. The goals of the European Commission are mainly to improve citizens' health by making health information available using digital health and care tools, including across border ones, to increase healthcare quality and access by making digital health and care part of health policy and coordinating EU member states' political, financial and technical strategies and to make digital health and care tools more effective, user-friendly and widely accepted by involving professionals and patients in strategy, design and implementation [9].

\section{1 eEurope Action Plan}

Healthcare systems are increasingly dependent on information and communication technologies. ICTs can help provide quality care for citizens. Clear steps for the field of electronization of healthcare are specifically set out in the "European eHealth Action Plan", see [11]. This is an overview of EU actions contributing to the creation of a European eHealth area [9]. The EU eHealth Action Plan covers the period from 2012 to 2020. It was launched in March 2011 as the second strategy (after 2004-2010 strategy) dedicated to the issue of healthcare electronization in the EU. It should provide opportunities to consolidate the steps already taken in this area. It provides a long-term vision of European eHealth in synergy with other documents as "Europe 2020" or the "Digital Agenda for Europe".

The policy objectives and initiatives for 2012-2020 cover:

- support of Member States and healthcare providers in that way that they can take benefit from ICT solutions in the best interests of patients, health care systems and society;

- helpful support towards the innovation of the environment and the best use of innovations in health care. 
In addition, eHealth Action Plan aims to ensure the successful achievement of the "Digital Agenda" goals and the goals of the document "European Innovation Partnership on active and healthy aging" such as:

- Raising awareness of the benefits and opportunities of eHealth, supporting citizens, patients and health professionals.

- Removing barriers to interoperability of eHealth.

- Enhancing legal certainty for eHealth.

- Supporting innovation and research in eHealth and developing a competitive European and global market.

However, the European Union does not only participate in a strategy on specific steps in the field of electronization of healthcare but also on other partial concepts and intentions. The basic health initiatives coordinated by the European Union include the standardization committees and the Working Party on eHealth. This group is aimed at work with EU Member States to solve the ICT issues and contribute to the effective implementation of the i2010 strategy of the "European Information Society for growth and employment", which preceded the eHealth Action Plan and set out the concrete goals for 2010 [15].

The European Commission is working to provide its citizens access to safe and top-quality digital services in health and care. As part of the Commission's "Digital Single Market strategy", three priorities for EU actions were identified in mid-term review [9]:

- Enable citizen's secure access to and use of health data across-borders.

- Support a cross-border data infrastructure to advance research and personalised medicine.

- Facilitate feedback and interaction between patients and health care providers, supporting citizen empowerment.

The "Horizon 2020 programme" contributes significantly in the area of digital technology for health and ageing. In this context, the "European Innovation Partnership on Active and Healthy Ageing" provides a platform to link the efforts of many regions and ecosystems across Europe, some of which are recognized as reference sites on digital innovation for health and care [9].

eHealth concept in individual EU member states is mainly influenced by the concept of eHealth in the EU legislation and the recommendations of the World Health Organization (WHO).

\subsection{Evaluation of eHealth in the European Union}

eHealth deployment in Europe is the subject of evaluation of international organizations such as EU or OECD. eHealth evaluation is described as an act to assess whether an eHealth system is functioning and producing the effects as expected [18]. Fostering the development and implementation of national eHealth policies and strategies has been a key goal of the European Union eHealth Action Plan of 2004. In 2011 the European Commission awarded the eHealth strategies study "European countries on their journey towards national eHealth infrastructures - evidence of progress and recommendations for cooperative actions", see [13], to a group of partners [6]. This is an overview and synthesis report on eHealth in Europe. The study team has analysed the progress of the European Union Member States with regard to the following eHealth action plan priorities [7]:

- National eHealth policies, strategies and governance measures. 
- Deployment of eHealth applications (EHR-like systems/patient summaries, ePrescription services and telehealth applications).

- Infrastructure implementation aspects (Electronic identifiers, eCards and standards).

- Institutional structures and legal issues.

The study results show that in virtually all European member states surveyed, political as well as stakeholder interest in eHealth policies, and the planning and implementation of national or regional infrastructures has strengthened considerably [6]. This comprehensive collection of country information constitutes a unique resource and important database of up to date evidence on eHealth progress across Europe updated and complemented the results of the earlier eHealth ERA study of 2007 [8].

In 2016, in cooperation with OECD the joint Commission and OECD report "Health at a Glance: Europe 2016" [20] was developed. New edition of "Health at a Glance" presents the most recent comparable data on the health status of populations and health system performance in OECD countries [21]. There was noted that the improvement in the adoption of digital technology in both the primary care and hospitals is needed across Europe. Many governments from Estonia to Portugal have already embarked on active eHealth policy implementation [21]. As another action of European Commission in the field of eHealth, a public consultation on the "Transformation of Health and Care in the Digital Single Market" was opened between July and October 2017. It gathered input on the scope of policy actions to be pursued in order to improve people's health and care. This consultation received nearly 1500 replies of which $90 \%$ of the respondents agree that citizens should be able to manage their own data. $80 \%$ of the respondents agree that sharing health data can be beneficial and around $60 \%$ of the respondents say that they do not have access to digital health services [9].

In 2017 the European Commission published a Eurobarometer survey [25] presenting European citizens' opinions on the impact of digitisation and automation on daily life. European citizens see digitisation and automation primarily as an opportunity but call for investment in better and faster internet services as well as effective public policy to accompany changes, in particular in areas such as employment, privacy and personal health. The results also show that the more people are informed or use technologies the more they are likely to have a positive opinion on them and to trust them. In the last 12 months, less than one in five respondents have used health and care services provided online (18\%). 52\% of all respondents would like to have online access to their medical and health records. Respondents are much more willing to share their health and wellbeing data with doctors and healthcare professionals $(65 \%)$ than with companies $(14 \%)$ or with public authorities, even if anonymised and for research purposes (21\%) [9].

The eHealth study from 2017 "Transforming eHealth into a political and economic advantage", see [3], evaluates the level of eHealth implementation in EU member states. In the results a lack of harmonisation of eHealth implementation within the EU and unsatisfactory access to cross-border healthcare is demonstrated.

\section{$2 \quad$ Research Objectives}

The article is focused on the comparison of eHealth implementation in the European Union member states by means of the multi-criteria decision-making methods. The aim is the evaluation of EU member states according to the state of eHealth by means of ELECTRE III method. The ELECTRE III method was used since it represents a suitable tool for the selection and creation of ranking of a larger number of variants. The data for the presented 
research were obtained from the study of European Commission on eHealth use among General Practitioners in EU [12].

In this paper, $27 \mathrm{EU}$ member states (variants) were analysed according to 12 eHealth indicators (criteria). The Netherlands is not included in the research as the required data were not available. The analysis is made by means of selected MCDM method - ELECTRE III method. ELECTRE III method belongs to the operations research methods and is based on the evaluation of preference relations. The basis is the examining of the relationships between pairs of variants [24].

Indicators I1 - I12 describe the level of eHealth use among General Practitioners in EU member states. They cover the areas of: Electronic Health Record (EHR), Health Information Exchange (HIE), Telehealth and Personal Health Record (PHR). The results of the research are summarized as the ranking of EU countries according to the level of eHealth in 2018.

\section{$3 \quad$ Research Methods}

The research is based on the application of multi-criteria decision-making methods. The data are processed by means of ELECTRE III method. The results are further verified by processing of MAPPAC method. The MAPPAC method was chosen because, apart from the information from the multi-criteria matrix and the vector of weights, it does not need any additional information such as threshold values or the choice of generalized criteria.

\subsection{ELECTRE III Method}

The basis of the ELECTRE method (Election et Choix Traduisant la Réalité) is to divide the variants into effective and inefficient. In the research the method ELECTRE III was used. ELECTRE III method provides the arrangement of variants into indifferent classes in which the variants are rated equally, but there is a preference relationship between indifferent classes. The index sets of criteria and the degree of preference are determined, without taking into account the degree of indifference. For each pair of variants $A i$ and $A j$ there are grouped criteria that prefer the $A i$ variant to the $A j$ variant, and the set of their indices is labelled $I_{i j}$, and there are groups of criteria that prefer the variant $A j$ before the $A i$ variant and their set of indices is denoted $I_{j i}$. The $A i$ variant is preferred to the $A j$ variant with the preference threshold c * if for the degree of preference of the $A i$ variant before the variant $A j$ it is greater than the preference degree of the variant $A j$ before the $A i$ variant while being greater than the threshold of preference $\mathrm{c} *$. The ELECTRE III method does not require the user to put preference thresholds, but the threshold values are gradually automatically generated. The variants are categorized into indifferent classes according to the indicator, which shows the difference between the number of variants before which the variant is preferred and the number of variants that are preferred before the given variant [26].

\subsection{MAPPAC Method}

MAPPAC method is the MCDM method based on paired comparisons of variants, whereby each pair of individual criteria results in a decision on which of the two objects is the more important, or whether they are indistinguishable in terms of the selected criteria. The MAPPAC method works with the criterion matrix and weights of the criteria. The method splits the variants into several preferential classes. MAPPAC method uses a normalized multicriteria matrix $C=\left(c_{i j}\right)$, where $r$-th row corresponds to variant $a_{r}$ and $s$-th row corresponds to variant $a_{s}$. First the paired comparison of variants is processed. On the basis of the results there are possible two relationships between variants. Either preference (variant $a$ was rated better than variant $b$ ) or indifference (variant $a$ and variant $b$ are assessed in the same way). In 
the last step preferences are aggregated, resulting in a final order. The row totals of the aggregated matrix $\pi$ are calculated according to the equation (1):

$$
\sigma^{l}\left(a_{i}\right)=\sum_{j=1}^{p} \pi\left(a_{i}, a_{j}\right), i \in J^{l}
$$

Variants with the highest $\sigma^{l}$ values are placed on the first place in the ranking. The set of variants is reduced from these variants, new set of variants $A^{l}$ is created, the set of indexes of variants from $A^{l}$ are marked as $J^{l}$. The procedure is repeated for $m$ steps where $m$ is the number of preferential classes by the ranking from above. In a similar procedure the value of $\tau^{1}, \tau^{2}, \ldots, \tau^{n}$ is reached, where $n$ is the number of preferential classes in the ranking from bottom, by usage of equation (2):

$$
\tau^{t}\left(a_{i}\right)=\sum_{j \in J^{t}} \pi\left(a_{j}, a_{i}\right), i \in J^{t}, t=1,2, \ldots n .
$$

The overall ranking of variants is reached by averaging of the serial numbers of variants by the ranking from above and bottom. As the best evaluated is the variant which has the lowest overall serial number [19].

\subsection{Weights of Criteria}

In calculations using ELECTRE, there are considered also the weights of individual criteria. All criteria are maximizing nature. The weights were determined by factor analysis made in the research of European Commission [12]. The four main areas (EHR, HIE, Telehealth and PHR) were the same weight as they are equally relevant to the assessment of the eHealth in EU member states. The weights of individual criteria were calculated in Tab. 1.

Tab. 1: Weights of eHealth indicators

\begin{tabular}{|l|l|c|}
\hline \multirow{5}{*}{ Area of eHealth } & Indicator $\left(\mathbf{I}_{1}-\mathbf{I}_{12}\right)$ & Weights of indicators \\
\hline \multirow{3}{*}{ EHR $(25 \%)$} & Health Info and Data $-\mathrm{I}_{1}$ & 0.0825 \\
\cline { 2 - 3 } & Clinical DSS - $\mathrm{I}_{2}$ & 0.0700 \\
\cline { 2 - 3 } & Order-entry management $-\mathrm{I}_{3}$ & 0.0450 \\
\cline { 2 - 3 } & Image $-\mathrm{I}_{4}$ & 0.0250 \\
\cline { 2 - 3 } & Admin $-\mathrm{I}_{5}$ & 0.0275 \\
\hline \multirow{2}{*}{ Telehealth $(25 \%)$} & Clinical data $-\mathrm{I}_{6}$ & 0.1425 \\
\cline { 2 - 3 } & Patient admin $-\mathrm{I}_{7}$ & 0.0600 \\
\cline { 2 - 3 } & Management $-\mathrm{I}_{8}$ & 0.0475 \\
\cline { 2 - 3 } & Clinical practice $-\mathrm{I}_{9}$ & 0.1275 \\
\cline { 2 - 3 } & Training $-\mathrm{I}_{10}$ & 0.1225 \\
\hline \multirow{2}{*}{ PHR $(25 \%)$} & Clinical info $-\mathrm{I}_{11}$ & 0.1400 \\
\cline { 2 - 3 } & Requests $-\mathrm{I}_{12}$ & 0.1100 \\
\hline
\end{tabular}

Source: [12], own calculations

\section{$4 \quad$ Results}

In this part of the article the application results of ELECTRE III method are presented. The results of the research are verified by MAPPAC method.

\subsection{Ranking of EU Countries by Usage of ELECTRE III Method}

Based on the results, it is possible to determine the order of the EU member states in terms of the eHealth implementation, from the best to the worst, as summarized in Tab. 2. 
Tab. 2: Ranking of EU countries according to eHealth by usage of ELECTRE III

\begin{tabular}{|l|l|l|l|}
\hline Order & Variant & Order & Variant \\
\hline 1 & Denmark & 15 & Cyprus \\
\hline 2 & Estonia & 16 & Romania \\
\hline 3 & Sweden & 17 & Greece \\
\hline 4 & Finland & 18 & Slovenia \\
\hline 5 & Spain & 19 & Poland \\
\hline 6 & United Kingdom & 20 & France \\
\hline 7 & Croatia & 21 & Ireland \\
\hline 8 & Italy & 22 & Bulgaria \\
\hline 9 & Hungary & 23 & Austria \\
\hline 10 & Czech Republic & 24 & Belgium \\
\hline 11 & Latvia & 25 & Luxembourg \\
\hline 12 & Malta & 26 & Slovakia \\
\hline 13 & Germany & 27 & Lithuania \\
\hline 14 & Portugal & N/A & Netherlands \\
\hline
\end{tabular}

Source: [12], own calculations

When evaluated by ELECTRE III method, the first five positions were occupied by Denmark, Estonia, Sweden, Finland and Spain. The worst state of eHealth was detected in Austria, Belgium, Luxembourg, Slovakia and Lithuania.

The EU member states reach the best results in the area of EHR. The best scores are achieved by Denmark and Estonia. EHR is a cornerstone of eHealth in the EU. This is the most developed part of EU eHealth in member states. The worst level in this indicator was observed in Lithuania. The area of HIE is developing in EU member states intensively. However, the level of implementation is significantly lower than in the case of EHR. The highest level is again in Denmark, Estonia and also in Sweden. The lowest level is in Malta, Poland, Greece and Slovakia. The least developed areas are Telehealth and PHR. These areas need a lot of support in the EU member states. Luxembourg, Slovakia and Romania lag most in these areas. On the contrary, the United Kingdom, Denmark and Finland are reaching the highest levels in Telehealth and PHR.

\subsection{Verification of the Results by Usage of MAPPAC Method}

EU member states ranked according to eHealth implementation based on the results of MAPPAC method are presented in Tab. 3. 
Tab. 3: Verification of the results by usage of MAPPAC method

\begin{tabular}{|l|l|l|l|}
\hline Order & Variant & Order & Variant \\
\hline 1 & Denmark & 13 & Belgium, Slovenia \\
\hline 2 & Estonia & 14 & Germany \\
\hline 3 & Finland & 15 & Cyprus \\
\hline 4 & United Kingdom & 16 & Austria \\
\hline 5 & Sweden & 17 & Bulgaria, Poland \\
\hline 6 & Spain & 18 & Romania \\
\hline 7 & Croatia & 19 & Greece \\
\hline 8 & Italy & 20 & Latvia \\
\hline 9 & Hungary & 21 & Luxembourg \\
\hline 10 & Czech Republic, Ireland & 22 & Slovakia \\
\hline 11 & France & 23 & Malta \\
\hline 12 & Portugal & 24 & Lithuania \\
\hline
\end{tabular}

Source: [12], own calculations

When evaluated by MAPPAC method, the first five positions were occupied by Denmark, Estonia, Finland, United Kingdom and Sweden. The worst state of eHealth was detected in Latvia, Luxembourg, Slovakia, Malta and Lithuania.

\section{Discussion}

According to the results of the presented research the implementation of eHealth in EU member states differ significantly. Based on the evaluation of eHealth in the EU member states, it was found that Denmark, Estonia, Sweden and Finland are on the top among EU member states when evaluating the practical usage of eHealth. The citizens there are generally keen to use the Internet and eHealth applications. In Denmark, for example, the health and care services provided online were used at least once a year by $42 \%$ of citizens (in Finland $49 \%$ and in Estonia 49\%), see [25]. The internet usage and literacy levels of a region are also often associated for example with higher levels of EHR adoption [21]. According to the study "Transforming eHealth into a political and economic advantage" from 2017, see [3], the implementation of electronic health records, ePrescriptions and national eHealth programmes varies significantly across EU member states. The best evaluated countries are Denmark, Finland, Spain and Sweden that have the most developed eHealth solutions. The result is similar to the research presented in this article.

However, there are also countries ranked near the average among EU member states. In these countries, there are mainly serious shortcomings, particularly on the side of public digital services providers. Changing the attitude of government officials in the area of eHealth promotion is therefore required (Czech Republic, Hungary).

The results were verified by another MCDM method - MAPPAC. It was confirmed that Denmark, Estonia, Finland, Sweden and also the United Kingdom are among the best rated countries in the field of eHealth. Luxembourg, Lithuania and Slovakia, on the other hand, are among the worst rated countries. A large difference was found in the case of Malta, which ranked differently in the ELECTRE III and MAPPAC ratings. Otherwise, the evaluation of countries was comparable by both methods. The difference in the result is due to the difference in methods and different calculation principles. While ELECTRE III method is based on effective and inefficient variants, MAPPAC is based on preference or indifference between variants. 
For the future of eHealth in EU member states, higher effort of European Commission in the field of eHealth harmonisation and standardisation is expected. Creation of common European registers of chronic diseases and actions to improve research data exchange between EU member states [3] are expected. The Commission was working with the member states to start exchanging e-prescriptions across borders in 2018. Cross-border telemedicine is a cornerstone of the "European Reference Networks" which will connect close to 1,000 clinics in Europe to diagnose and treat complex and rare diseases. Both schemes are supported by the "Connecting Europe Facility" and the system for exchange of prescriptions is based on a successful CIP project "epSOS" [9].

\section{Conclusion}

The article was focused on the evaluation of eHealth in the EU member states by means of MCDM methods. The research was based on the data set of the European Commission from the year 2018 .

The results of the evaluation of EU member states in terms of the implementation state of eHealth by ELECTRE III method have acknowledged that the best ranking in this area have obtained Denmark, Finland, Estonia and Sweden. The worst state of eHealth was reported in Luxembourg, Slovakia and Lithuania. The results were verified by MAPPAC method.

eHealth is a useful tool for reducing the costs and it is also a time-saving benefit for residents. In general, the EU member states show a good level of EHR implementation. However, other areas of eHealth (HIE, Telehealth and PHR) have not been sufficiently developed yet and remain a challenge for the future.

\section{Acknowledgements}

This article was created within the financial support of the student grant project SGS No. SP2020/32 "Economic evaluation of organizations providing public services related to the allocation function of public budgets" on Faculty of Economics, Technical University of Ostrava.

\section{Literature}

[1] ADEBESIN, F.; KOTZÉ, P.; van GREUNEN, D.; FOSTER, R.: Barriers and Challenges to the Adoption of E-Health Standards in Africa. In: Proceedings of Health Informatics South Africa 2013 (HISA 2013) Conference. 2013, pp. 1-9.

[2] AHAD, A.; TAHIR, M.; YAU, K.-L. A.: 5G-Based Smart Healthcare Network: Architecture, Taxonomy, Challenges and Future Research Directions. IEEE Access. 2019, Vol. 7, pp. 100747-100762. DOI: 10.1109/ACCESS.2019.2930628

[3] ARAK, P., WÓJCIK, A.: Transforming eHealth into a political and economic advantage. [online]. Polityka Insight. [online]. 2017. [accessed 2020-18-01]. Available from WWW: https://ec.europa.eu/digital-single-market/en/news/transforming-ehealthpolitical-and-economic-advantage

[4] CIPRESSO, P. et al.: Is your phone so smart to affect your state? An exploratory study based on psychophysiological measures. Neurocomputing. 2012, Vol. 84, pp. 23-30. DOI:10.1016/j.neucom.2011.12.027

[5] CHAUDHRY, B, et al.: Systematic review: impact of health information technology on quality, efficiency, and costs of medical care. Annals of Internal Medicine. 2006, Vol. 144, Issue 1, pp: 742-752. DOI: 10.7326/0003-4819-144-10-200605160-00125 
[6] DIGITAL HEALTH NEWS: European Countries on their Journey Towards National eHealth Infrastructures. [online]. 2011. [accessed 2020-08-02]. Available from WWW: http://www.ehealthnews.eu/publications/latest/2494--european-countries-on-theirjourney-towards-national-ehealth-infrastructures

[7] eHEALTH STRATEGIES: The European Union (EU) eHealth Action Plan of 2004. [online]. 2009. [accessed 2020-08-02]. Available from WWW: http://www.ehealthstrategies.eu/

[8] EMPIRICA: Towards the establishment of a European e-health research area. [online]. 2007. [accessed 2020-02-02]. Available from WWW: https://cordis.europa.eu/project/id/015854

[9] EUROPEAN COMMISSION: eHealth : Digital health and care. [online]. 2018 [accessed 2020-02-02]. Available from https://ec.europa.eu/health/ehealth/overview_en

[10] EUROPEAN COMMISSION: Redesigning health in Europe for 2020. [online]. 2012 [accessed 2020-02-02]. Available from https://ec.europa.eu/eip/ageing/library/redesigning-health-europe-2020_en

[11] EUROPEAN COMMISSION: eHealth action plan 2012-2010: Innovative healthcare for the 21st century. [online]. 2012. [accessed 2020-05-02]. Available from WWW: http://ec.europa.eu/health/ehealth/docs/com_2012_736_en.pdf

[12] EUROPEAN COMMISSION: Benchmarking deployment of eHealth among general practitioners (2018). [online]. 2018. [accessed 2020-07-07]. Available from WWW: https://op.europa.eu/en/publication-detail/-/publication/d1286ce7-5c05-11e9-9c52$\underline{01 \mathrm{aa} 75 \mathrm{ed} 71 \mathrm{a} 1}$

[13] EUROPEAN COMMISSION: European countries on their journey towards national eHealth infrastructures - evidence on progress and recommendations for cooperative actions. [online]. 2011. [accessed 2020-02-01]. Available from WWW: http://www.ehealthnews.eu/images/stories/pdf/ehstrategies_final_report.pdf

[14] EYSENBACH, G.: What is e-health? Journal of Medical Internet Research. 2001, Vol. 3, Issue 2. DOI: 10.2196/jmir.3.2.e20

[15] eZDRAV,cz: eHealth v EU. [online]. 2018. [accessed 2020-15-02]. Available from WWW: http://www.ezdrav.cz/ehealth-v-eu/

[16] GULlifORD, M.; MORGAN, M.: Access to Health Care. Psychology Press, New York, 2003. ISBN 0415275458, 9780415275453.

[17] JUNG, M.-L.; LORIA, K.: Acceptance of Swedish e-health services. Journal of Multidisciplinary Healthcare. 2010, Vol. 3, pp. 55-63. DOI: 10.2147/JMDH.S9159

[18] LAU, F.; KUZIEMSKY, C. (eds.): Handbook of eHealth Evaluation: An Evidencebased Approach. [online]. 2017. [accessed 2020-01-02]. ISBN-13 9781550586022, ISBN-13 9781550586039, ISBN-13 9781550586015. Available from WWW: https://dspace.library.uvic.ca//handle/1828/7814, https://www.ncbi.nlm.nih.gov/books/NBK481590/

[19] MARTEL, J.-M.; MATARAZZO, B.: Other Outranking Approaches. In: Greco, S. (ed.), Multiple Criteria Decision Analysis: State of The Art Surveys. International Series in Operations Research and Management Science. 2005, Vol. 78, pp. 197-259. eBook ISBN 978-0-387-23081-8. DOI: $10.1007 / \mathrm{b} 100605$ 
[20] OECD: Health at a Glance: Europe 2016: State of Health in the EU Cycle. [online]. 2016. DOI: 10.1787/9789264265592-en. [accessed 2020-04-08]. Available from WWW:

https://ec.europa.eu/health/sites/health/files/state/docs/health_glance_2016_rep_en.pdf

[21] OECD: Health at a Glance 2019. [online]. 2019. DOI: 10.1787/4dd50c09-en. [accessed 2020-04-08]. Available from WWW: http://www.oecd.org/health/healthsystems/health-at-a-glance-19991312.htm

[22] OH, H.; RIZO, C.; ENKIN, M.; JADAD, A.: What Is eHealth (3): A Systematic Review of Published Definitions. Journal of Medical Internet Research. 2005, Vol. 7, Issue 1. DOI: $\underline{10.2196 / j m i r .7 .1 . e 1}$

[23] STROETMANN, K. A. et al: European countries on their journey towards national eHealth infrastructures. Final European progress report. [online]. 2011. [accessed 2020-16-01]. Available from WW: http://www.ehealthstrategies.eu/report/eHealth_Strategies_Final_Report_Web.pdf

[24] ŠUBRT, T. et al.: Ekonomicko-matematické metody. Vydavatelství a nakladatelství Aleš Čeněk, s.r.o., Plzeň, 2015. EAN 9788073807627.

[25] EUROPEAN COMMISSION: Attitudes towards the impact of digitisation and automation and daily life. [online]. 2017. [accessed 2020-16-01]. Available from WWW: $\quad$ https://ec.europa.eu/digital-single-market/en/news/attitudes-towards-impactdigitisation-and-automation-daily-life

[26] HWANG, Ch.-L.; YOON, K. P.: Multiple Attribute Decision Making. An Introduction. Vol. 104. Series: Quantitative Applications in the Social Sciences. California: SAGE Publications, Inc. 1995. ISBN 9780803954861.

Ing. Eva Ardielli, Ph.D. 


\section{EHEALTH V EVROPSKÉ UNII - SROVNÁVACÍ STUDIE}

eHealth je jedním z moderních globálních trendů v oblasti IT, medicíny a politiky. Jedná se o široký pojem, který se týká elektronizace zdravotnictví a zdravotnických služeb, a hlavně popisuje použití informačních a komunikačních technologií ve zdravotnictví. V praxi je hodnocení eHealth důležitou záležitostí, protože vede k výběru vhodných opatření důležitých pro další pokrok $\mathrm{v}$ oblasti elektronické zdravotní péče a $\mathrm{k}$ návrhu doporučení pro rozvoj eHealth v zemích EU. Článek je zaměřen na komparaci stavu implementace eHealth v členských státech Evropské unie. Analýza je provedena metodou ELECTRE III. Výsledky empirického výzkumu hodnotí stav implementace eHealth ve všech členských státech Evropské unie podle vybraných kritérií a umožňují srovnání implementace eHealth v mezinárodním kontextu. Výsledky jsou ověřeny aplikací metody MAPPAC. Na základě výzkumu bylo potvrzeno, že nejlépe hodnocenými zeměmi v této oblasti jsou Dánsko, Finsko, Estonsko a Švédsko.

\section{EHEALTH IN DER EUROPÄISCHEN UNION - EINE VERGLEICHENDE STUDIE}

eHealth ist einer der modernen globalen Trends in IT, Medizin und Politik. Es ist ein weit gefasster Begriff, der das elektronische Gesundheitswesen und die Gesundheitsdienste betrifft und hauptsächlich den Einsatz von Informations- und Kommunikationstechnologien im Gesundheitswesen beschreibt. In der Praxis ist die Bewertung von eHealth ein wichtiges Thema, da sie zur Auswahl geeigneter Maßnahmen führt, die für weitere Fortschritte im Bereich eHealth wichtig sind, und zur Ausarbeitung von Empfehlungen für die Entwicklung von eHealth in EU-Ländern. Der Artikel konzentriert sich auf den Vergleich der Implementierung von eHealth in den Mitgliedstaaten der Europäischen Union. Die Analyse wird unter Verwendung der ELECTRE III-Methode durchgeführt. Die Ergebnisse der empirischen Forschung bewerten dann den Stand der Implementierung von eHealth in allen Mitgliedstaaten der Europäischen Union anhand ausgewählter Kriterien und ermöglichen den Vergleich der Implementierung von eHealth im internationalen Kontext. Die Ergebnisse werden durch Anwendung der MAPPAC-Methode verifiziert. Die Untersuchungen haben gezeigt, dass Dänemark, Finnland, Estland und Schweden die besten Positionen in diesem Bereich haben.

\section{E-ZDROWIE W UNII EUROPEJSKIEJ - BADANIA PORÓWNAWCZE}

e-Zdrowie to jeden $z$ nowoczesnych światowych trendów w dziedzinie IT, medycynie i polityce. To szerokie pojęcie, które dotyczy elektronizacji służby zdrowia i opieki zdrowotnej, opisujące przede wszystkim wykorzystanie technologii informacyjnokomunikacyjnych w służbie zdrowia. Ocena e-Zdrowia jest w praktyce istotną kwestią, gdyż przyczynia się do wyboru odpowiednich działań ważnych dla dalszego postępu w dziedzinie elektronicznej opieki zdrowotnej oraz do sformułowania zaleceń dotyczących rozwoju eZdrowia w krajach UE. Artykuł koncentruje się na porównaniu wdrażania e-Zdrowia w krajach Unii Europejskiej. Analiza wykonywana jest metodą ELECTRE III. Wyniki badań empirycznych oceniają stan wdrażania e-Zdrowia we wszystkich państwach członkowskich Unii Europejskiej według wybranych kryteriów i pozwalają na porównanie realizacji eZdrowia w kontekście międzynarodowym. Wyniki weryfikowane są metodą MAPPAC. Badania wykazały, że w tej dziedzinie przodują Dania, Finlandia, Estonia i Szwecja. 